\title{
Prioritising wetlands subject to secondary salinisation for ongoing management using aquatic invertebrate assemblages: a case study from the Wheatbelt Region of Western Australia
}

\author{
Jessica Delaney (1) - Russell J. Shiel • \\ Andrew W. Storey
}

Received: 3 February 2014/Accepted: 21 July 2015/Published online: 29 July 2015

(C) The Author(s) 2015. This article is published with open access at Springerlink.com

\begin{abstract}
Secondary salinisation is recognised worldwide as a threat to aquatic biodiversity. Wetlands in the Wheatbelt Region of Western Australia are particularly affected as a result of clearing of deeprooted native vegetation for agriculture. Between 1996 and 2001, the Western Australian government nominated six natural diversity recovery catchments (NDRCs), being catchments with high value and diverse wetlands in need of protection. One, the BuntineMarchagee NDRC, supports approximately 1000 wetlands in varying states of salinisation. The challenge is to prioritise these wetlands for ongoing management. In this paper we propose an approach to prioritise representative wetlands using aquatic invertebrates. On the basis of hydrology, salinity and remnant vegetation, 20 wetlands covering a range of salinities were selected for sampling of water quality and aquatic invertebrates. Of the 202 taxa recorded, most endemic taxa occurred in fresh/brackish wetlands, while hypersaline wetlands
\end{abstract}

J. Delaney $(\bowtie) \cdot$ A. W. Storey

Wetland Research \& Management, 16 Claude St.,

Burswood, WA 6100, Australia

e-mail: Jess.Delaney@WetlandResearch.com.au

R. J. Shiel

Ecology Evolution and Landscape Science, University of Adelaide, Adelaide, SA 5005, Australia

J. Delaney · A. W. Storey

School of Animal Biology, The University of Western Australia, 35 Stirling Highway, Crawley, WA 6009, Australia supported predominantly cosmopolitan species. Taxa richness was greater in fresh/brackish than saline and hypersaline wetlands, with conductivity explaining $83 \%$ of between-wetland variation in taxa richness. Classification using invertebrate assemblages separated fresh/brackish, saline and hypersaline wetlands, with greatest between-year variability within saline and hypersaline sites. Wetlands were ranked using taxa diversity, presence of conservation-significant taxa and temporal similarity. Mean rank across indices provided the final overall order of priority. Hypersaline wetlands were ordered separately to the fresher water wetlands (fresh/brackish and saline) so that priority for future management was detailed for both types of wetlands. The analysis indicated that although fresh/brackish sites support the highest biodiversity, naturally saline sites also supported wetland assemblages worthy of ongoing protection.

Keywords Macroinvertebrates - Zooplankton · Salinity $\cdot$ Wheatbelt Region $\cdot$ Management

\section{Introduction}

In many semi-arid countries of the world, secondary salinisation poses one of the greatest threats to aquatic biodiversity (Williams 2001). Most often this is in the form of dryland salinity; where deep-rooted native vegetation has been cleared and replaced with annual crops for agriculture. This leads to a hydrological 
imbalance, with less water uptake by vegetation and an increase in recharge. Ultimately, salt stored in the soil profile becomes mobilised as groundwater levels rise, bringing saline water to the surface. This results in waterlogging and increased salt concentrations in both terrestrial and aquatic habitats (Davis et al. 2003; Nielsen et al. 2003). Aquatic systems are low-lying in the landscape, so tend to be the first to show symptoms of elevated salt concentrations.

It has been estimated that 60 million ha of irrigated land, and 61-77 million ha of arid land are affected by secondary salinity worldwide (Marshall and Bailey 2004). Within Australia, at least 5.7 million ha of land are affected, or lie within regions designated 'at risk' (NLWRA 2001). Of this affected land, more than 1 million ha occurs within the Wheatbelt Region of Western Australia, and this is expected to increase two-fourfold by 2050 (George et al. 2006). The extent of secondary salinisation in this region has been considered a major social, ecological and economic disaster (Davis et al. 2003; Pannell and Ewing 2006). The economic costs of salinisation not only relates to the loss of agricultural production, but also to damage to infrastructure including roads, rail and towns (Pannell 2001). This loss of production can result in less viable farms and reduced incomes, impacting on provision of services and the social fabric of rural towns (Pannell 2001). Other social costs relate to the increased incidence of disease. For example, the Ross River virus (RRV) mosquito vector Aedes camptorhynchus (Thomson, 1868) was found to be more abundant in saline areas of the Wheatbelt, and importantly, the potential for transmission of RRV, a debilitating human viral infection, was positively correlated with both increasing salinity and abundance of A. camptorhynchus (Carver et al. 2009). It was concluded that the preservation and/or restoration of freshwater Wheatbelt habitats may reduce the potential for transmission of the RRV disease (Carver et al. 2009). Secondary salinisation also has implications for the ecology of wetlands, including reducing diversity of aquatic invertebrates (Pinder et al. 2005), changing aquatic invertebrate assemblage composition (Pinder et al. 2004), and altering habitat such as the loss of aquatic and fringing vegetation (Froend 1987).

In recognition of the impacts of secondary salinisation on biodiversity, and particularly the ecological health of wetlands, the Western Australian Department of Conservation and Land Management (now known as DPaW: Department of Parks and Wildlife) established the regionally coordinated natural diversity recovery catchments (NDRCs) program as part of the state salinity action plan (SAP), which subsequently became known as the state salinity strategy (Wallace 2001). The aim of the NDRC program was to identify major, high priority biological assets that were at risk from salinity and warrant significant, ongoing investment for their recovery and protection (Wallace 2001). The program operated at the catchment level, as this was the level at which groundwater tables and recharge had to be controlled to manage the issue. Six NDRCs were identified in Western Australia, including the catchments of Lake Toolibin, Lake Bryde, Lake Warden, Lake Muir-Unicup, Drummond, and Buntine-Marchagee. While the primary goal of recovery catchments was conservation of biodiversity, the NDRC program also investigated solutions to reverse salinisation, and therefore provided an opportunity to develop generic solutions for salinity management that could be implemented throughout the region (Wallace 2001).

The state salinity strategy aspires to protect all biodiversity assets threatened by salinity; however, given the magnitude of the problem and the reality of limited resources, it is necessary prioritise sites in order to maximise the ecological values or functions to be conserved or restored. The identification of priority areas of ecological significance has been used worldwide to assist management goals and reduce costs (i.e., Hoctor et al. 2000). Although a number of methodologies have been developed for terrestrial and marine ecosystems, few are specific to inland waters. In Western Australia, the selection of the recovery catchments was designed to protect individual high-value wetlands, such as Ramsar wetlands (Lake Toolibin, Muir-Byenup and Lake Warden) and wetlands of national importance (i.e., Lake Bryde) (Environment Australia 2001), while other catchments were designated for the protection of suites of diverse wetlands (i.e., Buntine-Marchagee and MuirUnicup catchments). The selection of multiple wetlands reflects the need to not only maintain biodiversity within an individual wetland, but to maintain a variety of wetland types within a catchment, in order to conserve biodiversity at a regional scale. The challenge then arises of how to prioritise specific wetlands for individual management within a large catchment holding many wetlands of differing types and condition. In this paper we propose an approach to prioritise representative 
wetlands utilising aquatic invertebrate diversity, using the Buntine-Marchagee NDRC (BMNDRC) as a case study.

The Buntine-Marchagee catchment supports more than 1000 individual wetlands, covering a diversity of types and salinity conditions, ranging from fresh, but now being affected by secondary salinisation, through to naturally saline, and saline becoming hypersaline. Studies of terrestrial vegetation (Richardson et al. 2005), groundwater (Speed and Strelein 2004) and hydrogeology have been undertaken within the catchment (Richardson et al. 2005). However, little was known of the aquatic fauna of the BMNDRC wetlands, what species they support, and how assemblages vary amongst wetland types. Only a small number of sites within, and adjacent to, the catchment have previously been sampled (i.e., Cale et al. 2004; Pinder et al. 2004). Given limited resources and the large number of wetlands in the catchment, the aim was to characterise the aquatic fauna of different wetland types using a subset of wetlands representative of the range of wetland types and salinities present. Knowledge of assemblages and conservation value of the aquatic fauna could then be used to prioritise the wetlands for future management.

Based on surveys of vegetation, hydrology and hydrogeology (Richardson et al. 2005; Speed and Strelein 2004), DPaW selected 20 wetlands from the BMNDRC to encompass the geographical spread along the main braided drainage system, variety of different physical characteristics, range of different types of remnant vegetation communities, and the range of conductivities from fresh through to hypersaline. The wetlands tended to be those in best physical condition, or most representative of a subset of wetlands. In this paper we describe how aquatic invertebrate assemblages vary across the 20 wetlands, relate the occurrence of invertebrates to salinity levels, and propose a method to "prioritise" wetlands for ongoing management with the aim of protecting them from ongoing secondary salinisation.

\section{Methods}

Study area and sampling sites

The Wheatbelt is a major cereal growing region of Australia, and covers an area of approximately
$225,000 \mathrm{~km}^{2}$ in the south-west of Western Australia. It has a Mediterranean climate, with hot dry summers and cool wet winters. Average annual rainfall decreases from $\sim 600 \mathrm{~mm}$ in the south-west to $\sim 300 \mathrm{~mm}$ in the north-east (Gentili 1972).

The BMNDRC is located in the Northern Wheatbelt Region, in the vicinity of the towns of Dalwallinu, Wubin, Buntine and Marchagee, approximately $250 \mathrm{~km} \mathrm{NNE}$ of Perth, the capital of Western Australia. The catchment covers an area of approximately 181,000 ha, of which around $87 \%$ has been cleared for broad acre agriculture consisting of cereal cropping and sheep farming. The BMNDRC contains more than 1000 discrete wetlands of varying types including primary saline braided wetland channels, fresh/brackish wetlands, freshwater claypans, granitic rock pools and wetlands with unusual gypsum and bentonite substrata. Close to $70 \%$ of these wetlands occur low in the landscape and are at risk from waterlogging and salinity.

Twenty wetlands were selected for sampling, 19 of which were within the catchment, and 1 (SPS203) situated on the catchment boundary was included for comparative purposes as it had been sampled previously. All sites were sampled in winter (August) of 2004 and 2005 (Fig. 1; Table 1).

Field sampling

At each wetland, a graduated pole was used to measure average (m) and maximum water depth (m), as well as thickness of salt crust, if present. The extent of vegetative cover of the area within and immediately adjacent to where samples were collected was visually assessed as an indication of habitat composition. Percentage cover was recorded for (1) riparian vegetation (i.e., plants along the margins of the wetland but not in the water, consisting of Eucalyptus spp., Melaleuca spp., Acacia spp., Hakea spp., Grevillea spp. and various grasses and understorey species), (2) samphire (i.e., saltbush, principally of the genera Tecticornia and Sarcocornia, that occur along the margins and into areas of shallow inundation within the wetland), (3) submerged aquatic macrophytes (i.e., submerged aquatic plants found within the wetland itself, such as Ruppia spp., Chara spp. and Nitella spp.), (4) emergent reeds and rush (i.e., perennial plants that grow alongside the waterbody and in shallow margins, mostly Typha spp. and Juncus spp.), 


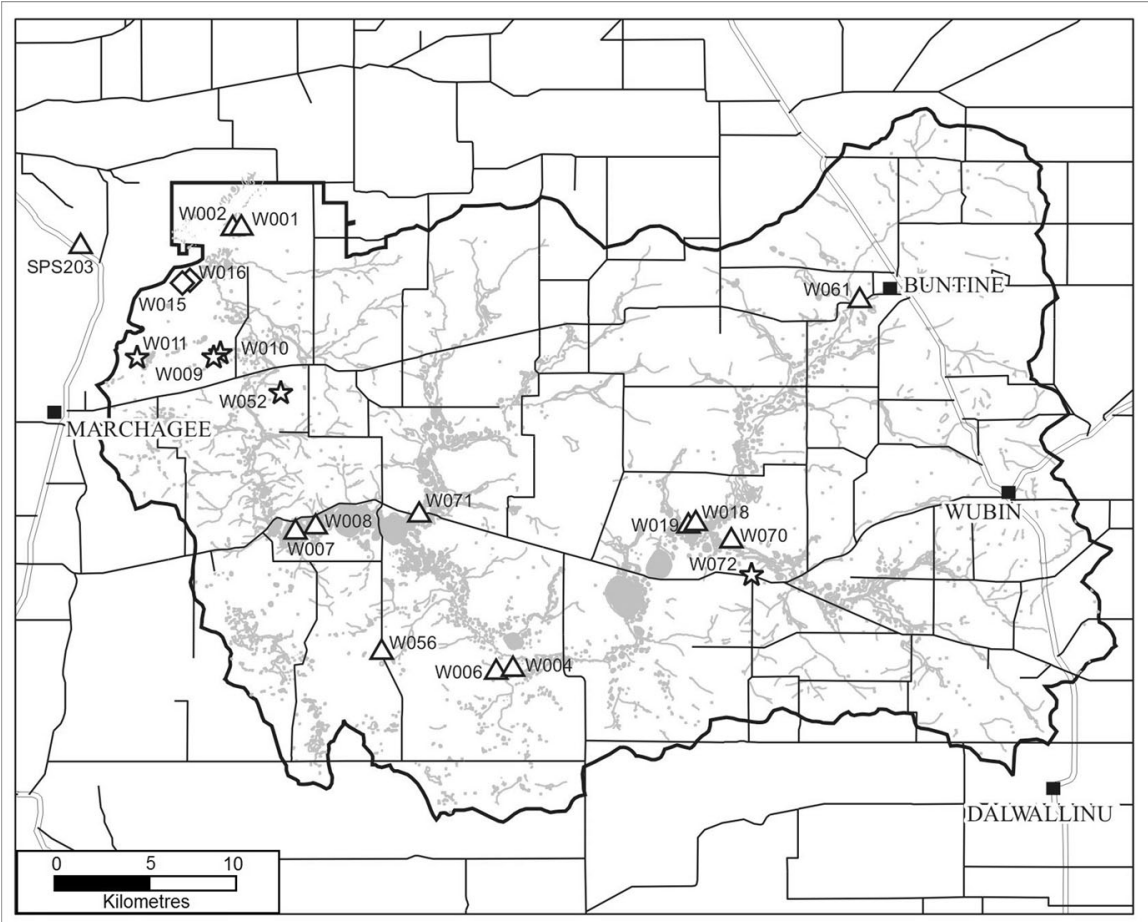

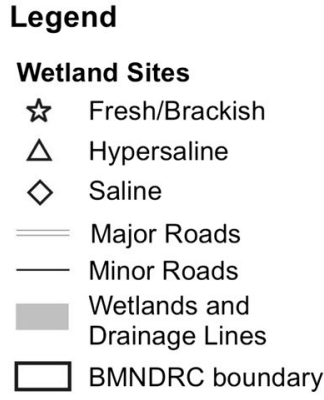

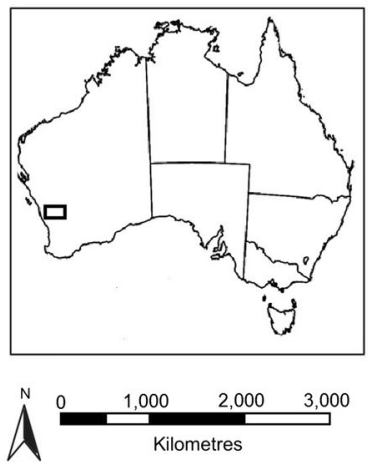

Fig. 1 Map of the study area, showing the salinity category of each site

and (5) open sediment (i.e., non-vegetated sediment). Total vegetative cover (\%) was also recorded. In addition, the presence of any cyanobacterial benthic mat was noted, with both thickness ( $\mathrm{mm}$ ) and percent cover recorded.

Methodology for invertebrate sampling was consistent with that used to survey 200 wetlands across the Wheatbelt in 1996 as part of the SAP (Cale et al. 2004). Zooplankton and macroinvertebrates were sampled separately at each wetland using standard D-frame $350 \mathrm{~mm}$ diameter FBA pond nets of 50 and $250 \mu \mathrm{m}$ mesh size, respectively. Samples consisted of $50 \mathrm{~m}$ of discontinuous sweep netting within wadeable depth, with the aim of maximising diversity by incorporating all habitats. In order to ensure the finer mesh net did not get clogged, zooplankton sampling avoided disturbing benthic sediments (i.e., sampled the water column, and through any submerged macrophytes). However, macroinvertebrate sampling consisted of vigorous kick-sweep sampling of all habitats, including benthic sediments. Macroinvertebrate samples were preserved in $70 \%$ ethanol, whilst zooplankton samples were preserved in $4 \%$ formaldehyde in situ and then transferred to ethanol in the laboratory.

Physico-chemical parameters were measured in situ using a Yeo-Kal portable water quality analyser (model 611), including dissolved oxygen (\%), pH and water temperature $\left({ }^{\circ} \mathrm{C}\right)$. Water samples for laboratory analyses were collected towards the centre of each wetland, with samples taken midway through the water column prior to disturbance by fauna sampling. Electrical conductivity $(\mathrm{mS} / \mathrm{m})$, colour (TCU) and turbidity (NTU) were measured from an unfiltered $250 \mathrm{~mL}$ sample. Chlorophyll $a$ was measured from a 1 L sample of water filtered through a GFC filter paper that was then frozen and returned to the laboratory. Chlorophyll $a$ analysis was by acetone extract, as per APHA iCHLA1WAC (APHA, AWWA, WEF 1995). Total nitrogen and total phosphorus were determined from a $100 \mathrm{~mL}$ water sample filtered in the field through a $0.45 \mu \mathrm{m}$ Millipore acetate filter and then frozen for return to the laboratory. Analysis of nutrient concentrations was by persulphate digestion FIA (APHA 4500N-C, I for total nitrogen and APHAP-J, $\mathrm{G}$ for total phosphorus; 1995). Chlorophyll $a$, total 
Table 1 The 20 wetlands sampled in 2004 and 2005

\begin{tabular}{|c|c|c|c|c|}
\hline Site numbers & Easting (GDA 94) & Northing (GDA 94) & Size (ha) & $\begin{array}{l}\text { Permanent or } \\
\text { ephemeral waterbody }\end{array}$ \\
\hline W001 & 420,779 & $6,686,836$ & 9.4 & Ephemeral \\
\hline W002 & 420,300 & $6,686,700$ & 15.8 & Ephemeral \\
\hline W004 & 436,629 & $6,658,695$ & 1.7 & Ephemeral \\
\hline W006 & 435,593 & $6,658,319$ & 0.8 & Ephemeral \\
\hline W007 & 424,152 & $6,667,100$ & 100.4 & Ephemeral \\
\hline W008 & 425,436 & $6,667,124$ & 6.9 & Ephemeral \\
\hline W009 & 419,738 & $6,677,933$ & 1.0 & Permanent \\
\hline W010 & 419,925 & $6,678,046$ & 0.5 & Ephemeral \\
\hline W011 & 415,399 & $6,678,363$ & 20.6 & Ephemeral \\
\hline W015 & 418,063 & $6,683,732$ & 0.1 & Ephemeral \\
\hline W016 & 418,350 & $6,683,750$ & 3.0 & Ephemeral \\
\hline W018 & 446,489 & $6,667,322$ & 59.6 & Ephemeral \\
\hline W019 & 446,124 & $6,667,125$ & 2.4 & Ephemeral \\
\hline W052 & 423,483 & $6,676,606$ & 0.1 & Ephemeral \\
\hline W056 & 429,170 & $6,658,511$ & 1.8 & Ephemeral \\
\hline W061 & 456,233 & $6,682,500$ & 3.8 & Ephemeral \\
\hline W070 & 448,357 & $6,666,425$ & 17.7 & Ephemeral \\
\hline W071 & 431,443 & $6,668,132$ & 16.6 & Ephemeral \\
\hline W072 & 449,886 & $6,664,269$ & 0.5 & Ephemeral \\
\hline SPS203 & 411,460 & $6,685,610$ & 4.7 & Ephemeral \\
\hline
\end{tabular}

nitrogen and total phosphorus analyses were undertaken by the ChemCentre of Western Australia.

\section{Sample processing}

In the laboratory, macroinvertebrates were sorted under a dissecting microscope and specimens were identified to species using appropriate taxonomic keys (i.e., Davis and Christidis 1997; Gooderham and Tsyrlin 2002; Timms 2004), and by reference to a voucher collection held by the authors. Each species was enumerated using a $\log _{10}$ abundance scale, where $1=1$ individual, $2=2-10$ individuals, $3=11-100$ individuals, and so on. Zooplankton samples were processed by identifying the first 200-300 individuals encountered in an agitated sample decanted into a $125 \times 125 \mathrm{~mm}$ gridded plastic tray, with the tray then scanned for additional missed taxa. Zooplankton specimens were identified to the lowest taxon possible using keys/references cited in Shiel (1995), and enumerated using the $\log _{10}$ abundance scale.
Data analysis

Wetlands were a priori classified as either fresh/ brackish, saline or hypersaline based on ANZECC/ ARMCANZ (2000) salinity classifications. Fresh/ brackish wetlands were defined as those with conductivities less than $8.8 \mathrm{mS} / \mathrm{cm}$. One of the sites classified within this category was the only freshwater site of the 20 wetlands sampled in the BMNDRC (site \# W072; conductivity of $0.5 \mathrm{mS} / \mathrm{cm}$ in 2004 and $0.6 \mathrm{mS} / \mathrm{cm}$ in 2005). Wetlands classified as saline were in the range $8.8-50 \mathrm{mS} / \mathrm{cm}$ and those categorised as hypersaline had conductivities greater than $50 \mathrm{mS} / \mathrm{cm}$ (i.e., exceeding sea water).

Levene's test was used to test for homogeneity of sample variances prior to undertaking two-factor analysis of variance (ANOVA) to compare differences in both environmental and biotic data between wetland types and years. Where significant effects were detected, a Tukey's HSD post hoc test was conducted to identify spatial/temporal differences. Proportional 
data were arcsin transformed prior to analysis. Where the Levene's test indicated variances were not homogenous, transformations were applied until this assumption was satisfied (square root or natural $\log$ transformations). For some vegetation data (i.e., percent reed/rush, percent total vegetative cover, percent samphire and percent riparian vegetation) it was not possible to satisfy the assumption of equality of variance since hypersaline wetlands typically supported no vegetation, and therefore sample variance was zero for that sub-set. All univariate statistics were performed using SPSS software (version 19.0 for Windows).

Environmental and biotic assemblage data were analysed using PRIMER v6 (Plymouth routines in multivariate ecological research; Clarke and Gorley 2006) to investigate relationships between assemblages and physico-chemical characteristics. Ordination of data was achieved by multi-dimensional scaling (MDS; Clarke and Green 1988) using the Bray-Curtis similarity coefficient (1957). MDS of environmental data was based on the Euclidean distance measure, using standardised and log transformed data where appropriate (Clarke and Gorley 2006). Analysis of similarity (ANOSIM) was conducted on a priori groups (i.e., year and salinity category) to test for significant differences between groups. The SIMPER routine (Clarke 1993) was used to identify those taxa contributing to the formation of different groups (as ascertained with ANOSIM). A Monte-Carlo permutation procedure using the RELATE test (Clarke et al. 1993; Clarke and Warwick 1994) was used to correlate the matrices from the invertebrate assemblage structure (biotic) and environmental group data. Relationships between environmental and biotic data were then assessed using BIOENV. To illustrate temporal change within individual wetlands, between-year pairwise similarities were calculated using the Bray-Curtis similarity measure.

Based on results of above analyses, wetlands were then divided into two groups; hypersaline and fresher water wetlands (including fresh/brackish and saline), and within these groups, wetlands were prioritised for future monitoring on the basis of three metrics; species richness, presence of conservation significant taxa and within-site temporal similarity. Invertebrate species richness has long been used as an indicator in biological monitoring studies as invertebrates respond to change in water quality and available habitat, and generally, species richness is highest in more pristine/less disturbed environments (Miserendino et al. 2008). In addition, using species richness as a parameter for determining priority wetlands ensures the greatest biodiversity is conserved, which is the aim of most management strategies worldwide (Sutherland et al. 2009). The presence of species listed as being of conservation significance within a wetland, including species listed on the IUCN Redlist, locally or regionally restricted species and/or species new to science, would also afford a wetland a higher priority because of the conservation value of such species. The management of wetlands that support conservationsignificant species would assist in the maintenance of biodiversity and ensure no loss of species. Finally, within-site temporal similarity was considered a useful parameter for prioritising wetlands given that sites that exhibit high natural variability, but with little change to habitat and/or the absence of any obvious anthropogenic impact, limit the ability to detect change in communities over time (Ham and Pearsons 2000). From a management perspective, wetlands that show low temporal change provide the best sites for rehabilitation trials, as changes in response to management actions are more likely to be apparent and statistically detectable.

Using these three metrics, the wetlands were given a rank score for (a) total number of invertebrate taxa recorded, (b) the number of conservation significant taxa, and (c) percent temporal pairwise similarity. The rank scores given to each wetland for each metric were then averaged, and the wetlands were ordered according to their mean rank. All indices were weighted equally.

\section{Results}

Environmental data

For the majority of variables, there were significant differences between salinity categories (Table 2). A difference between years was only recorded for dissolved oxygen and chlorophyll $a$ (Table 2). In support of the salinity category definitions, the mean conductivity of each category was significantly different from each other, with no temporal difference and no significant interaction (Table 2). A number of 
Table 2 Two-factor ANOVAs on environmental data. Groups not joined by a common line are significantly different from each other $(\alpha=0.05)$. Groups are arranged in ascending order, with mean values in parentheses. Where transformations have been applied, geometric means are provided

\begin{tabular}{|c|c|c|c|c|c|c|c|}
\hline Parameter & Source & df & $F$ & $\bar{p}$ & & Tukeys post-hoc test & \\
\hline \multirow[t]{3}{*}{ DO } & Salinity Category & 2 & 3.81 & 0.032 & Saline (56.38) & Hypersaline (67.65) & Fresh/Brackish (72.34) \\
\hline & Year & 1 & 343.11 & 0.000 & $2004(29.86)$ & 2005 (105.54) & \\
\hline & Salinity ${ }^{\star}$ Year & 2 & 8.57 & 0.001 & & & \\
\hline \multirow[t]{3}{*}{ Temp } & Salinity Category & 2 & 3.04 & 0.061 & & & \\
\hline & Year & 1 & 17.14 & 0.000 & $2005(13.1)$ & $2004(16.8)$ & \\
\hline & Salinity ${ }^{\star}$ Year & 2 & 2.711 & 0.081 & & & \\
\hline \multirow[t]{3}{*}{ Cond (In) } & Salinity Category & 2 & 142.13 & 0.000 & Fresh/Brackish (2.48) & Saline (15.79) & Hypersaline (108.75) \\
\hline & Year & 1 & 0.08 & 0.777 & & & \\
\hline & Salinity ${ }^{\star} Y e a r$ & 2 & 0.07 & 0.931 & & & \\
\hline \multirow[t]{3}{*}{ Colour (In) } & Salinity Category & 2 & 24.11 & 0.000 & Hypersaline (11.87) & Fresh/Brackish (28.00) & Saline (460.27) \\
\hline & Year & 1 & 0.09 & 0.766 & & & \\
\hline & Salinity ${ }^{\star} Y e a r$ & 2 & 0.28 & 0.761 & & & \\
\hline \multirow[t]{3}{*}{ Depth } & Salinity Category & 2 & 3.46 & 0.043 & Hypersaline (0.24) & Saline (0.32) & Fresh/Brackish (0.43) \\
\hline & Year & 1 & 2.75 & 0.106 & & & \\
\hline & Salinity ${ }^{*} Y e a r$ & 2 & 0.62 & 0.543 & & & \\
\hline \multirow[t]{3}{*}{ Total_P (In) } & Salinity Category & 2 & 8.28 & 0.001 & Fresh/Brackish (0.02) & Hypersaline (0.02) & Saline $(0.07)$ \\
\hline & Year & 1 & 0.97 & 0.333 & & & \\
\hline & Salinity ${ }^{*} Y e a r$ & 2 & 0.20 & 0.818 & & & \\
\hline \multirow[t]{3}{*}{ Chl a (In) } & Salinity Category & 2 & 0.17 & 0.849 & & & \\
\hline & Year & 1 & 43.78 & 0.000 & $2004(0.00)$ & $2005(0.07)$ & \\
\hline & Salinity ${ }^{\star} Y e a r$ & 2 & 0.87 & 0.422 & & & \\
\hline \multirow[t]{3}{*}{ Veg cover } & Salinity Category & 2 & 9.16 & 0.001 & Hypersaline (0.14) & Fresh/Brackish (0.54) & Saline (0.55) \\
\hline & Year & 1 & 0.01 & 0.933 & & & \\
\hline & Salinity ${ }^{*} Y e a r$ & 2 & 1.24 & 0.301 & & & \\
\hline \multirow[t]{3}{*}{ Reed/rush } & Salinity Category & 2 & 4.49 & 0.019 & Hypersaline (0) & Saline (0.11) & Fresh/Brackish (0.15) \\
\hline & Year & 1 & 0.18 & 0.674 & & & \\
\hline & Salinity ${ }^{*} Y e a r$ & 2 & 0.11 & 0.893 & & & \\
\hline \multirow[t]{3}{*}{ Samphire } & Salinity Category & 2 & 13.81 & 0.001 & Fresh/Brackish (0) & Hypersaline (0.02) & Saline (0.36) \\
\hline & Year & 1 & 0.78 & 0.382 & & & \\
\hline & Salinity ${ }^{\star} Y e a r$ & 2 & 0.23 & 0.799 & & & \\
\hline \multirow[t]{3}{*}{ Riparian veg } & Salinity Category & 2 & 3.77 & 0.033 & Saline (0) & "Hypersaline (0) & Fresh/Brackish (0.01) \\
\hline & Year & 1 & 0.24 & 0.625 & & & \\
\hline & Salinity ${ }^{*} Y e a r$ & 2 & 0.04 & 0.957 & & & \\
\hline
\end{tabular}


variables showed no significant difference between either years or salinity category, including $\mathrm{pH}$, total nitrogen, turbidity, benthic mat thickness, percent cover of benthic mat and percent macrophyte cover (Table 2).

Taxonomic composition

A total of 202 taxa were recorded from the 20 wetlands sampled in 2004 and 2005. Most taxa were considered tolerant of a wide range of environmental conditions and are common, ubiquitous and frequently encountered in wetland systems within Western Australia. Of note, however, was the collection of a number of species known only from the south-west of the State, including the Conchostraca Caenestheriella packardi (Brady, 1886), Anostraca Parartemia contracta (Linder, 1941), Parartemia serventyi (Linder, 1941) and $P$. longicaudata (Linder, 1941), chironomids Dicrotendipes conjunctus (Walker, 1856) and Procladius villosimanus (Kieffer, 1917), and the hydrophilid Coleoptera Helochares tenuistriatus (Régimbart, 1908). The Anostraca, P. contracta, is listed as vulnerable on the IUCN Redlist of Threatened Species (Inland Water Crustacean Specialist Group 1996). A locally endemic species of chironomid, Chironomus occidentalis (Skuse, 1889), also was collected from wetlands in the BMNDRC (sites W009, W010 and W061). The majority of endemic taxa occurred in the fresh/brackish wetlands, with the exception of the anostracans $P$. contracta and $P$. longicaudata, and the chironomid Cladopelma sp. nov. which occurred in hypersaline wetlands. Sites W010 and W011 had the greatest number of south-west Australian and locally restricted endemic taxa. Hypersaline wetlands tended to support predominantly cosmopolitan species.

Of conservation significance was the collection of two species new to science: the rotifer Hexarthra sp. recorded from W072, and the chironomid Cladopelma sp. nov. from W011, W052 and SPS203. In addition, two rotifer species constituted new records, one for Australia [Hexarthra propinqua (Bartos, 1948) from W001 and W002] and one for Western Australia [Proales daphnicola (Thompson, 1892) from W009].

Three introduced species were collected, including the freshwater crayfish Cherax destructor (Clark, 1936) from W052, the aquatic snail Physa acuta (Draparnaud, 1805) from W072 and the fairy (brine) shrimp Artemia parthenogenetica (Bowen and Sterling, 1978) from W006, W019 and W070.

\section{Taxa richness}

Invertebrate taxa richness varied between site and year (Fig. 2). The greatest number of taxa was recorded from W072 in 2004 (52 taxa) whilst the least was recorded from W007 in 2005 (only one taxon; see Fig. 2). Taxa richness was significantly different between wetlands of varying salinity, and was significantly greater in brackish wetlands when compared with saline and hypersaline wetlands (Table 3). Although a greater number of taxa was recorded from saline wetlands when compared with hypersaline wetlands, this difference was not significant (Table 3).

There was a strong inverse relationship between wetland conductivity $(\log x+1)$ and taxa richness, with the number of taxa decreasing as conductivity increased (Fig. 3). Over $83 \%$ of the between-wetland variation in taxa richness was explained by wetland conductivity $\left(y=-18.35 x+47.43 ; R^{2}=0.84 ;\right.$ Fig. 3).

\section{Patterns in community structure}

Invertebrate assemblage composition was significantly different between the three wetland groups (Fig. 4; ANOSIM, global $\mathrm{R}=0.26, \mathrm{p}=0.002$ ). Post hoc analysis revealed invertebrate communities were not significantly different between saline and hypersaline wetlands $(p=0.36)$, but were different between brackish and saline $(\mathrm{p}=0.003)$, and between brackish and hypersaline wetlands $(\mathrm{p}=0.001)$.

The average dissimilarity of invertebrate assemblages between hypersaline and brackish wetlands was extremely high (SIMPER; $89.9 \%$ ). Brackish wetlands were found to be typified by Daphnia carinata (King, 1853) (Cladocera), Boeckella triarticulata (Thomson, 1883) (Copepoda: Calanoida), the chironomids Tanytarsus fuscithorax (Skuse, 1889), P. villosimanus, Polypedilum nubifer (Skuse, 1889) and Limnophyes pullulus (Skuse, 1989) (Diptera), Micronecta robusta (Hale, 1922) (Hemiptera), Agraptocorixa eurynome (Kirkaldy, 1897) (Hemiptera), Allodessus bistrigatus (Clark, 1862) (Coleoptera), Orthetrum caledonicum (Brauer, 1865) (Anisoptera), Hemianax papuensis (Burmeister, 1839) (Anisoptera) and Austrolestes annulosus (Selys, 1862) (Zygoptera). Saline wetlands were generally characterised by Diacypris sp. 
Fig. 2 Total invertebrate taxa richness recorded from each site during each year

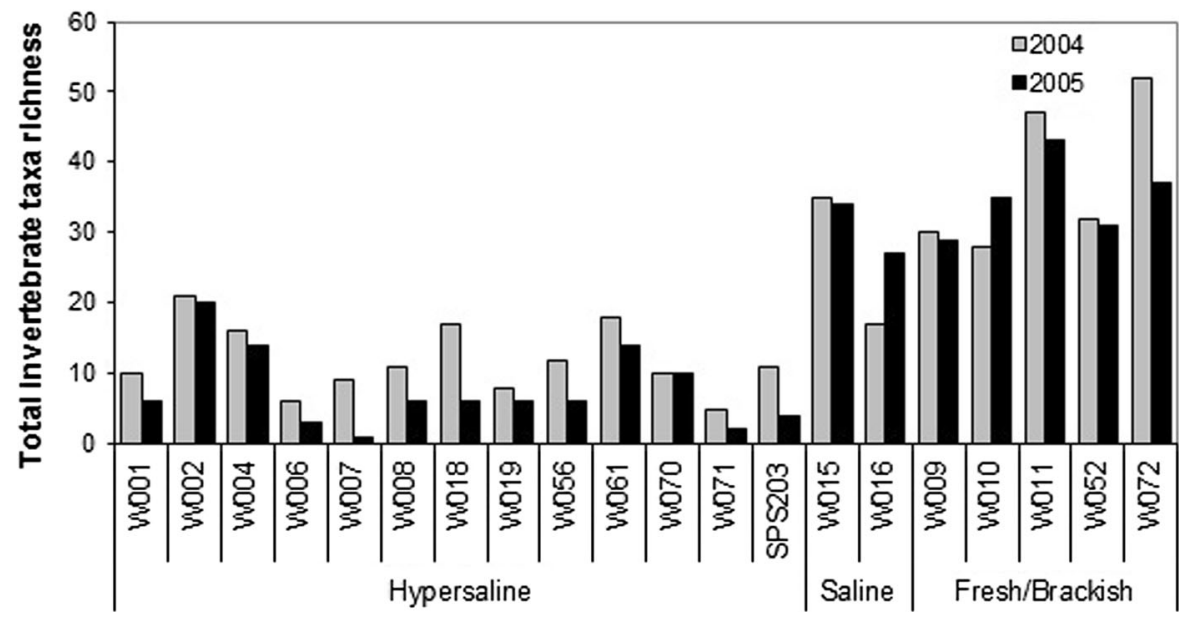

with mean values in parentheses. Where transformations have been applied, geometric means are provided
Table 3 Two-factor ANOVA for taxa richness data. Groups not joined by a common line are significantly different from each other $(\alpha=0.05)$. Groups are arranged in ascending order,

\begin{tabular}{|c|c|c|c|c|c|c|c|}
\hline Parameter & Source & df & $F$ & $p$ & & Tukeys post-ho & \\
\hline \multirow[t]{3}{*}{ Taxa richness (In) } & Salinity Category & 2 & 53.99 & 0.000 & Hypersaline (7.92) & Saline (27.19) & Fresh/Brackish (35.62) \\
\hline & Year & 1 & 0.28 & 0.630 & & & \\
\hline & Salinity*Year & 2 & 1.31 & 0.282 & & & \\
\hline
\end{tabular}

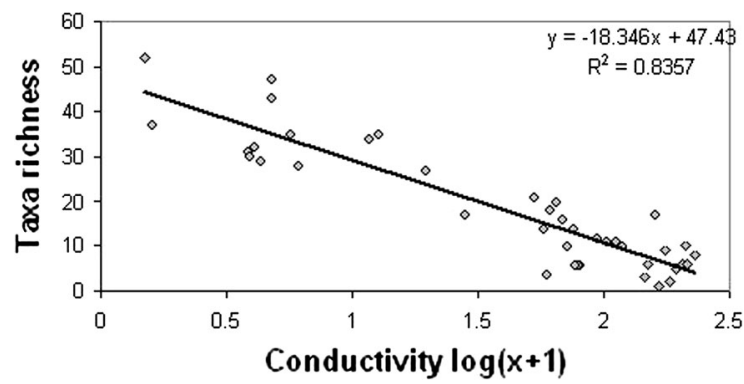

Fig. 3 Linear regression between wetland conductivity $\log (x+1)$ and taxa richness, showing regression equation and $\mathrm{R}^{2}$ value

(Ostracoda), the chironomids Chironomus aff. alternans (Diptera) and Tanytarsus semibarbitarsus (Glover, 1973) (Diptera), Ephydridae spp. (Diptera), Culicinae spp. (Diptera), and Hemicordulia tau (Selys, 1871) (Anisoptera). The amphipod Austrochiltonia subtenius (Sayce, 1902) was common to both brackish and saline wetlands, as was the chironomid Procladius

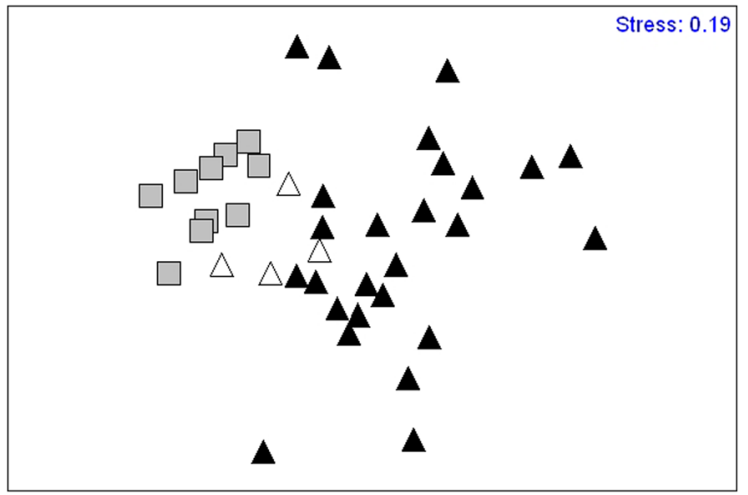

Fig. 4 MDS ordination of the 20 wetlands sampled in 2004 and 2005, using presence/absence data. Symbols indicate salinity category; filled triangles hypersaline, filled squares fresh/ brackish, and open triangles saline

paludicola (Skuse, 1889). Taxa dominant within hypersaline wetlands were Meridiecyclops baylyi (Fiers, 2001) (Copepoda: Cyclopoida), Australocypris cf. insularis (Ostracoda), T. barbitarsus (Freeman, 


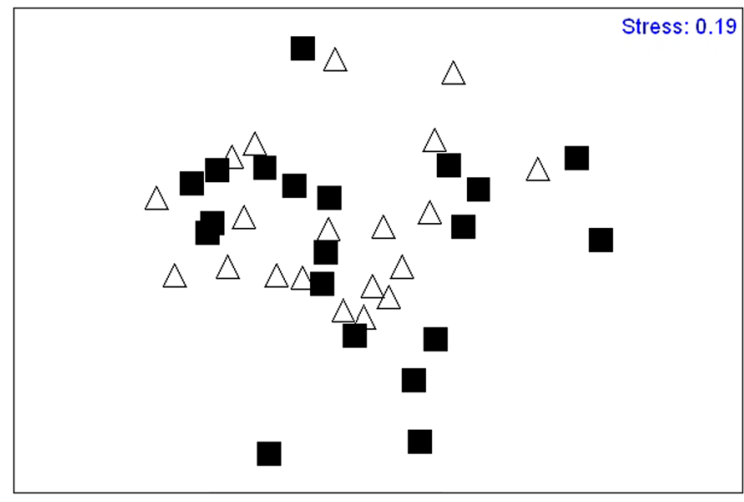

Fig. 5 MDS ordination of the 20 wetlands sampled in 2004 and 2005 , using presence/absence data. Symbols indicate year; open triangles 2004, and filled squares 2005

1961) (Diptera: Chironomidae), Muscidae spp. (Diptera), Tabanidae spp. (Diptera) and A. parthenogenetica (Anostraca).

The similarity matrices for the environmental and invertebrate community group structure were significantly correlated (RELATE, sample statistic $=0.175, \mathrm{p}=0.007)$. Furthermore, patterns in the invertebrate community data were found to be influenced by five environmental variables: percent cover of total vegetation, samphire, reeds/rushes, riparian vegetation and macrophytes (BIOENV). Of these, percent total vegetative cover and percent samphire cover particularly were influenced by salinity (Table 2). Percent vegetative cover was lowest in hypersaline wetlands but similar in saline and brackish sites (Table 2), whereas cover of samphire was significantly greater in saline wetlands when compared with brackish and hypersaline sites (Table 2).

Temporal variability

There was no significant difference in invertebrate assemblage structure between years (Fig. 5; ANOSIM, global $\mathrm{R}=0.045, \mathrm{p}=0.09$ ). However, between-year pairwise similarity ranged from $0 \%$ at hypersaline site W071 to around $67 \%$ at brackish site W010 (Table 4). In 2004, four taxa were recorded from W071, while in 2005 two entirely different taxa were collected. Temporal change in community structure at the hypersaline SPS203 was also considerable, and this was reflected in the low percentage pairwise similarity (13\%). It is suggested this wetland dried between the 2004 and 2005 surveys, resulting in
Table 4 Between-year percent pairwise similarity

\begin{tabular}{lll}
\hline Sites & Salinity category & \% Pairwise similarity \\
\hline W001 & Hypersaline & 62.50 \\
W002 & Hypersaline & 48.78 \\
W004 & Hypersaline & 60.00 \\
W006 & Hypersaline & 22.22 \\
W007 & Hypersaline & 20.00 \\
W008 & Hypersaline & 35.29 \\
W009 & Fresh/brackish & 50.85 \\
W010 & Fresh/brackish & 66.67 \\
W011 & Fresh/brackish & 55.56 \\
W015 & Saline & 60.87 \\
W016 & Saline & 45.45 \\
W018 & Hypersaline & 34.78 \\
W019 & Hypersaline & 57.14 \\
W052 & Fresh/brackish & 44.44 \\
W056 & Hypersaline & 44.44 \\
W061 & Hypersaline & 56.25 \\
W070 & Hypersaline & 50.00 \\
W071 & Hypersaline & 0.00 \\
W072 & Fresh/brackish & 33.71 \\
SPS203 & Hypersaline & 13.33 \\
& Average & 43.11 \\
\hline
\end{tabular}

a distinctly different invertebrate assemblage between years. Generally, brackish $($ mean $=50.2 \%)$ and saline wetlands $($ mean $=53.2 \%)$ had higher between-year percentage similarities than hypersaline sites $($ mean $=38.8 \%$ ), however this difference was not significant (Table 4; one-way ANOVA, df $=19$, $F=1.07, \mathrm{p}>0.05)$.

Priority wetlands

Hypersaline wetlands with the greatest number of invertebrate taxa were W002, W004 and W061 (Table 5). Sites showing little between-year variation were W001, W004, W019 and W061 (Table 5). The greatest number of conservation significant taxa was recorded from W002. The rotifer, H. propinqua, was found at W002. The hypersaline wetlands were then ordered on the average rank across the three metrics (Table 5), with the top five ranked sites being W002, W004, W061, W001 and W019.

The highest taxa richness from fresher water wetlands within the BMNDRC were recorded from 
Table 5 Rank of hypersaline wetlands based on total number of invertebrate taxa, percent temporal similarity and number of conservation significant taxa

\begin{tabular}{lllll}
\hline Sites & $\begin{array}{l}\text { Total invertebrate } \\
\text { taxa rank }\end{array}$ & $\begin{array}{l}\text { \% Temporal } \\
\text { similarity rank }\end{array}$ & $\begin{array}{l}\text { Conservation significant } \\
\text { taxa rank }\end{array}$ & $\begin{array}{l}\text { Mean } \\
\text { rank }\end{array}$ \\
\hline W002 & 1 & 6 & 1 & 2.67 \\
W004 & 2 & 2 & 4 & 2.67 \\
W061 & 2 & 4 & 4 & 3.33 \\
W001 & 5 & 1 & 4 & 3.33 \\
W019 & 5 & 3 & 4 & 4.00 \\
W070 & 4 & 5 & 4 & 4.33 \\
W008 & 5 & 8 & 2 & 5.00 \\
W056 & 5 & 7 & 4 & 5.33 \\
W018 & 5 & 9 & 4 & 6.00 \\
SPS203 & 10 & 12 & 2 & 8.00 \\
W006 & 11 & 10 & 4 & 8.33 \\
W007 & 13 & 11 & 4 & 9.33 \\
W071 & 12 & 13 & 4 & 9.67 \\
\hline
\end{tabular}

Table 6 Rank of fresher wetlands (fresh/brackish and saline) based on total number of invertebrate fauna, percent temporal similarity and number of conservation significant fauna

\begin{tabular}{lllll}
\hline Sites & $\begin{array}{l}\text { Total invertebrate taxa } \\
\text { rank }\end{array}$ & $\begin{array}{l}\text { \% Temporal similarity } \\
\text { rank }\end{array}$ & $\begin{array}{l}\text { Conservation significant } \\
\text { taxa rank }\end{array}$ & $\begin{array}{l}\text { Mean } \\
\text { rank }\end{array}$ \\
\hline W011 & 1 & 3 & 1 & 1.67 \\
W010 & 4 & 1 & 2 & 2.33 \\
W009 & 5 & 4 & 3 & 4.00 \\
W072 & 2 & 7 & 5 & 4.67 \\
W015 & 6 & 2 & 6 & 4.67 \\
W016 & 8 & 5 & 6 & 6.33 \\
W052 & 7 & 6 & 6 & 6.33 \\
\hline
\end{tabular}

W011, W072, W010, W009 and W015 (Table 6). Wetlands with high percent pair-wise similarity between years (i.e., low variation over time) were W010, W015, W011, W009 and W016. Of particular conservation importance was the new Cladopelma species from W011, new species of Hexarthra (rotifer) and Orthocladiinae (chironomid) from W072, and the collection of $P$. daphnicola (rotifer) from W009. The fresher wetlands were then ordered on the average rank across the three metrics (Table 6), with the top five ranked sites being W011, W010, W009, W072 and W015.

\section{Discussion}

In this study, a representative suite of 20 wetlands was sampled from within, and adjacent to, the BMNDRC.
The wetlands encompassed the geographical spread along the main braided drainage system, the variety of different physical characteristics, the range of different types of remnant vegetation communities, and the range of conductivities from fresh through to hypersaline. An average richness of $\sim 10$ taxa was recorded from hypersaline wetlands, $\sim 28$ taxa from saline wetlands and $\sim 36$ taxa in brackish wetlands. This diversity was relatively low when compared with other studies of its type worldwide (Hammer et al. 1990; Aladin et al. 1998), as well as other studies from wetlands in higher rainfall regions of Western Australia. Storey et al. (1993) recorded 72, 96 and 85 taxa from three freshwater wetlands on the south coast of Western Australia during winter. Brackish Thomsons Lake, the most species-rich wetland studied on the Swan Coastal Plain, close to Perth, supported 60 taxa (Davis and Rolls 1987). When compared with other 
Western Australian Wheatbelt wetlands, average richness recorded during the current study was comparable or slightly low. For example, Pinder et al. (2005) reported maximum diversity of less than 20 taxa from hypersaline wetlands, Lyons et al. (2007) recorded 39 invertebrate taxa from saline Lake Eganu, but over four sampling occasions, and Halse et al. (2000) recorded 63 taxa from the brackish Lake Walbyring.

Although generally comprising common, ubiquitous species, the BMNDRC wetlands also contained species endemic to the south-west of Western Australia, species locally endemic, a species listed on the IUCN Redlist of Threatened Species, two species new to science, and new records for Australia and Western Australia. This study provides an important baseline documenting the ecological values of the system, and details how the ecological values vary between wetlands. The protection and management of all 1000 wetlands within the BMNDRC would be a difficult task, therefore the characterisation of the fauna was a necessary step in prioritising the wetlands to guide management actions.

\section{Defining salinity categories}

Salinity categories used in wetland assessment vary between studies, and the question of defining salinity categories has been the focus of some debate. Williams (1964) proposed a value of $>3000 \mathrm{mg} / \mathrm{L}$ $(\sim 4.5 \mathrm{mS} / \mathrm{cm})^{1}$ to define saline waters based on the concentration at which a 'brackish taste' became obvious. The value of defining salinity categories based on mammalian taste was later debated by Bayly (1967) and Hammer (1986), and a more ecologically appropriate classification of $1000 \mathrm{mg} / \mathrm{L}(\sim 1.5 \mathrm{mS} /$ $\mathrm{cm})$ to $10,000 \mathrm{mg} / \mathrm{L}(\sim 14.9 \mathrm{mS} / \mathrm{cm})$ was suggested by Bayly (1967). Hart and McKelvie (1986) agreed with this classification, as $10,000 \mathrm{mg} / \mathrm{L}$ is the approximate upper salinity tolerance of many commonly occurring freshwater organisms. Wollheim and Lovvorn (1995) defined oligosaline lakes as those being $0.8 \mathrm{mS} / \mathrm{cm}$ ( $536 \mathrm{mg} / \mathrm{L})$ to $8.0 \mathrm{mS} / \mathrm{cm}(\sim 5360 \mathrm{mg} /$ $\mathrm{L})$, and mesosaline lakes as those between 8.0 and 30.0 $\mathrm{mS} / \mathrm{cm} \quad(\sim 20,100 \mathrm{mg} / \mathrm{L})$. The Australian Water Resources Council adopted a concentration of

\footnotetext{
${ }^{1}$ A conversion factor of 0.67 was used to convert $\mathrm{mg} / \mathrm{L}$ to $\mu \mathrm{S} /$ $\mathrm{cm}$ as recommended by ANZECC/ARMCANZ (2000).
}

$5000 \mathrm{mg} / \mathrm{L}(\sim 7.5 \mathrm{mS} / \mathrm{cm})$ as the lower limit for salinity (AWRC 1987). Classifications used in the current study were similar to this, with fresh/brackish wetlands being those with salinities $\leq 8.8 \mathrm{mS} / \mathrm{cm}$ ( $\sim 5896 \mathrm{mg} / \mathrm{L})$ and saline wetlands having salinities between 8.8 and $50 \mathrm{mS} / \mathrm{cm}(\sim 33,500 \mathrm{mg} / \mathrm{L})$. Therefore, there are no universally accepted thresholds for defining wetland salinity categories, however, the categories used in the current study are supported by significant differences in aquatic fauna between the wetlands sampled.

Invertebrate assemblages

Invertebrate richness showed a strong inverse relationship to salinity, with richness decreasing as salinity increased. This finding is consistent with studies of lentic (i.e., Hammer 1986; Halse et al. 2003; Blinn et al. 2004; Pinder et al. 2005) and lotic waters throughout the world (i.e., Bunn and Davies 1992; Wollheim and Lovvorn 1995; Griffith et al. 2001), which consistently show salinity to be a major factor influencing community composition in aquatic systems.

The invertebrate communities of the BMNDRC wetlands appear to display some tolerance to high salinities, with most taxa that occur in brackish wetlands also occurring in saline wetlands, but not in hypersaline wetlands. The average taxa richness was significantly reduced in wetlands with salinities greater than $50 \mathrm{mS} / \mathrm{cm}$. It is considered that in the Wheatbelt, historical exposure to salinity as a result of significant landscape and catchment disturbance, due mostly to agricultural practices, has led to the evolution of diverse halobiont invertebrate communities (Remigio et al. 2001; Marshall and Bailey 2004). It has therefore been suggested that the diversity of aquatic fauna from this region has been reduced to a subset of taxa that are resilient and halotolerant (Marshall and Bailey 2004). Whilst the relative salt-tolerance of Wheatbelt invertebrates has been documented, nearly half of these invertebrates only occur in naturally saline waterbodies with undisturbed hydrological regimes (Pinder et al. 2005). Secondary salinisation is believed to pose a threat even to salt-adapted species because many cannot tolerate the altered hydroperiod associated with secondary salinisation (Cale et al. 2004). While many genera have evolved over geological time to inhabit a range of salinities, individual 
populations show limited tolerance to rapid change (i.e., Marshall and Bailey 2004). Bunn and Davies (1992) suggest that native freshwater species may be able to survive increases in salinity of $0.05 \mathrm{ppt}(\sim 0.07$ $\mathrm{mS} / \mathrm{cm})$ to $0.25 \mathrm{ppt}(\sim 0.37 \mathrm{mS} / \mathrm{cm})$ above their normal threshold range, but only if the change is incremental.

Although the invertebrate taxa of the BMNDRC may have evolved some tolerance to salt, loss of diversity would occur if salinities increased further as a result of secondary salinisation. For example, saltsensitive fauna occurring within the brackish suite of wetlands would be lost. Fauna recorded from the BMNDRC considered to be most sensitive to further increases in salinity were the Cladocera $D$. carinata (Palmer and Scherman 2000), Copepoda B. triarticulata, Chironomidae T. fuscithorax, Odonata $O$. caledonicum and H. papuensis (Hart et al. 1991), and the Corixidae M. robusta and A. eurynome. All of these taxa were recorded only from the fresh/brackish and saline wetlands, and were notably absent from hypersaline wetlands of the BMNDRC.

Invertebrate communities showed a strong relationship with vegetative cover, and, as would be expected, vegetative cover was related to salinity levels, with the hypersaline wetlands having significantly less cover. Saline wetlands, however, were characterised by a high cover of salt-tolerant samphire, which was not observed at any of the brackish wetlands. This is consistent with the literature, since elsewhere, an increase in salinity has resulted not only in reduced plant species richness, but also a change in plant species composition (Hart et al. 1991; Lymbery et al. 2003). Many aquatic invertebrates are reliant on vegetation, whether riparian or aquatic, since it provides habitat (Strayer and Malcom 2007), protection from predators and a source of food (Smock and Stoneburner 1980). As such, changes in riparian and aquatic plant communities ultimately impact diversity of aquatic invertebrates (Naiman and Décamps 1997). Impacts to riparian vegetation associated with dryland salinity can be a consequence of both elevated soil salinities and waterlogging (Hart et al. 1991; Lymbery et al. 2003). The majority of riparian flora of streams and wetlands throughout Australia are non-halophytes and vulnerable to the effects of increased salinity (Rozema 1975).

The invertebrate assemblages of the BMNDRC wetlands showed some degree of temporal variability.
Hypersaline sites showed considerable change between years, however, these wetlands supported low taxa richness, and so a change in only a small number of taxa would result in relatively high variation between years (i.e., a low percent pairwise similarity). Temporal variability in aquatic invertebrate fauna is common, even when samples are taken in the same manner from the same habitat and location (McElvray et al. 1989). Temporal variation can be correlated with hydrological cycle (Tarr et al. 2005), changes in riparian and aquatic vegetation (viz. habitat change; i.e., Balla and Davis 1995) and the ecology/ life cycle characteristics of the invertebrates themselves (Porst et al. 2012). Changes can also be related to drought or flood, as well as disturbance such as fire (Minshall 2003).

The influence of changes in hydrology and hydroperiod on aquatic invertebrate assemblages of BMNDRC wetlands was evident at site SPS203. This site was sampled as part of the SAP in 1999 (Wallace 2001), following exceptionally high winter rainfall and local flooding. Consequently, water levels were higher and salinity lower (4.2 ppt compared with 70 ppt in 2004) at SPS203 in 1999 than anytime during the current study. The high water levels in 1999 also resulted in marginal riparian vegetation being flooded, providing increased habitat diversity; this habitat was not flooded during the current study. Invertebrate diversity was also higher in 1999 (54 taxa) than 2004 (9 taxa). Therefore, these saline wetlands are able to support far greater diversity when fresh and recently filled. This may be due to aquatic invertebrates with aerial adult stages opportunistically colonising the wetland, but may also be due to emergence of freshwater-adapted residents whose resting eggs are deposited along the high water mark and only emerge infrequently when the wetland is full, fresh and water levels reach this mark.

\section{Priority wetlands}

Characterisation of wetland types on aquatic invertebrate fauna has demonstrated that each type of wetland has distinct faunas with distinct attributes. The challenge for managers is to decide which wetlands to protect. Analyses indicated that fresher water sites, including fresh/brackish and saline wetlands, recorded greater diversity and number of conservation significant species than hypersaline wetlands; however, 
hypersaline wetlands also have value because they support a suite of invertebrates not found in the fresher sites. Therefore, in order to maintain regional biodiversity, wetlands across the range of types must be protected. The initial selection of wetlands for sampling was based on comprehensive studies of vegetation values (i.e., Richardson et al. 2005), groundwater modelling (i.e., Speed and Strelein 2004) and hydrogeology (i.e., Richardson et al. 2005), with the selected wetlands considered the most representative of their type. Scoring and ranking on the basis of aquatic fauna values identified high ranking wetlands in each group for ongoing monitoring and management. The highest ranking wetlands would be considered priority wetlands and would be considered the best wetlands in terms of vegetation and hydrology, but also in terms of aquatic invertebrate values for management and protection.

The fresher water (including fresh/brackish and saline) and hypersaline wetlands supporting the greatest number of invertebrate taxa and showing the least between-year variation were prioritised for future monitoring and management. In addition to supporting unique fauna, hypersaline site W001 was considered a unique wetland within the catchment as it has naturally low $\mathrm{pH}$ and the bed consists of a layer of gypsum crystals, with no other occurrence of this type of wetland known in the catchment.

The final number of wetlands selected for ongoing management will ultimately depend on the funding and resources available, as well as proximity to other high priority wetlands. Where broader landscape approaches are used, for example, there would be benefit in selecting groups of priority wetlands in close proximity in order to gain maximum impact from the management strategy.

The metrics chosen for prioritising wetlands in and adjacent to, the BMNDRC were deemed the most useful in this setting. However, the inclusion of different metrics may apply to different suites of wetlands. For example, diversity of fish might be a valuable metric as fish tend to be good indicators of ecosystem health (Hugueny et al. 1996; An and Choi 2003), and they are relatively easy to sample and identify. Of the wetlands sampled, only one (W009) supported a species of fish, the Swan River goby Pseugobius olorum (Sauvage, 1880), and on only one sampling occasion. As such, fish diversity was not a useful metric in this study. Another potential metric might be the presence of invasive species, such that sites which support introduced or invasive species are afforded a lower priority rank than those in which they are absent.

\section{Introduced species}

Introduced species are recognised globally as a major threat to biodiversity and ecosystem health (Pimentel et al. 2005). Deleterious impacts such as predation on, and competition with, native species (Lynas et al. 2006), alteration of food webs (Nyström et al. 1999) and the introduction of diseases (Levy 2004) have been reported. Three introduced species were recorded from the BMNDRC; the snail P. acuta, brine shrimp $A$. parthenogenetica and crayfish $C$. destructor.

Native to Europe, the Nearctic region and the neotropical region, $P$. acuta is thought to have been introduced by European settlers (Smith 1996). It is now found across the Australian continent, and appears to be actively spreading (Smith 1996). It is a long-established occupant of wetlands and river systems within various parts of south-western Australia. The introduction of this species in the Murray River of South Australia has been implicated in declines of native gastropod species, including the ecologically similar Glyptophysa gibbosa (Gould, 1846) (Zukowski and Walker 2009). P. acuta appears to be reasonably sensitive to salinity, with a reported $72 \mathrm{~h} \mathrm{LC50}$ of $12.6 \mathrm{mS} / \mathrm{cm}$ (Kefford et al. 2006), no hatching success of eggs above $12 \mathrm{mS} / \mathrm{cm}$ (Kefford et al. 2004) and a significant reduction in growth between 1 and $5 \mathrm{mS} / \mathrm{cm}$ (Kefford and Nugegoda 2005). P. acuta was only recorded from the fresh/ brackish wetland W072.

The method of introduction of the brine shrimp, $A$. parthenogenetica, within Australia, is currently contentious, with some holding the view that they were intentionally introduced for aquaculture (e.g., Williams 1981). More recently, the view that Artemia spread by natural means from Asia has gained wide support (e.g., McMaster et al. 2007; Timms 2004). The spread of Artemia into natural waterways where they will likely co-occur with native anostracans is of concern. They seem particularly suited to conditions common to wetlands of the BMNDRC, showing a preference for hypersaline waters (Timms 2004).

The yabby, $C$. destructor, a crayfish native to eastern Australia, was first introduced to Nareembeen 
in the Western Australian Wheatbelt District, approximately $280 \mathrm{~km}$ to the east of Perth, in 1932 (Morrissy and Cassells 1992). This species has proved to be a highly successful invasive species and has since spread throughout much of the south-west of the state (Lynas et al. 2004). Its presence in natural aquatic systems is of concern owing to its highly aggressive nature (Lynas et al. 2007) and superior competitive ability (Lynas et al. 2004, 2006). This species is also tolerant of a wide range of environmental conditions, has the ability to exploit a wide variety of different aquatic habitats, including semi-permanent swamps, billabongs, irrigation channels, and deeper, permanent streams and rivers (Austin 1985), and produces a large number of offspring (Beatty et al. 2005). They are more tolerant of salinity than local native freshwater crayfish and are known to survive in salinities up to $17,000 \mathrm{mg} / \mathrm{L}$ ( $\sim 25.4 \mathrm{mS} / \mathrm{cm})$. C. destructor was recorded from a fresh/brackish category wetland (W052). It is likely that if salinity continues to increase, this species will not survive.

\section{Management of wetlands}

Secondary salinisation comes with high social, economic and environmental costs. Waterlogging and salinisation takes agricultural land out of production, damages infrastructure such as roads, railways and buildings, and impacts wetlands, waterways and their dependent fauna and flora. The solutions are expensive and not always socially acceptable, and need to be applied at the catchment or at least sub-catchment scale, to reduce infiltration and reverse rising water tables. There is also a challenge in implementing management actions that will not subsequently impact the aquatic ecosystems in other ways. For example, deep drainage has been implemented in some agricultural areas to combat rising groundwater levels, and saturation of lower lying land. The intent is to drain low-lying land, using a network of deep drains and bunding (an artificial embankment that prevents water entering a wetland, diverting it to a drain). However, these drains often intercept acid sulphate soils, leading to acidification of nearby wetlands, as has occurred elsewhere in the Wheatbelt (Stewart et al. 2009).

From an environmental perspective, protecting the few remaining healthy wetlands in a catchment is a high priority, whether it is to protect freshwater wetlands from going saline or naturally brackish or saline wetlands from becoming hypersaline. Either scenario results in the loss of endemic species of conservation value. The approach described here will help identify these higher value wetlands for conservation and management.

Acknowledgments This Project was funded by the Department of Conservation and Land Management, now known as DPaW, under the State Salinity Strategy. Glen Daniel and Jodie Watts are thanked for overall project management on behalf of DPaW. Wesley Manson, Gaven Mullan and Melissa Cundy are also thanked for their respective roles in the Project. Lisa Chandler provided assistance with the 2005 fieldwork as well as macroinvertebrate identifications. Assistance from various taxonomists is also acknowledged, including Mark Harvey for Hydracarina (WA Museum) and Donald Edward for Chironomidae (UWA). A macroinvertebrate voucher collection was lodged with $\mathrm{DPaW}$ and verified by Jane McRae.

Funding Sources This work was funded by the Australian Government under the Natural Heritage Trust (National Action Plan for Salinity and Water Quality), with funds provided to the Northern Agricultural Catchments Council, and managed by the Western Australian Department of Environment and Conservation (now known as the Department of Parks and Wildlife).

\section{Compliance with ethical standards}

Conflict of interest The authors declare that there is no conflict of interest.

Open Access This article is distributed under the terms of the Creative Commons Attribution 4.0 International License (http:// creativecommons.org/licenses/by/4.0/), which permits unrestricted use, distribution, and reproduction in any medium, provided you give appropriate credit to the original author(s) and the source, provide a link to the Creative Commons license, and indicate if changes were made.

\section{References}

Aladin NV, Filippov AA, Plotnikov IS, Orlova MI, Williams WD (1998) Changes in the structure and function of biological communities in the northern part of the Aral Sea (Small Aral Sea), 1984-1994. Int J Salt Lake Res 7:301-343

An K, Choi S (2003) An assessment of aquatic ecosystem health in a temperate watershed using the index of biological integrity. J Environ Sci Health A 38:1115-1131

ANZECC/ARMCANZ (2000) Australian and New Zealand guidelines for fresh and marine water quality. Australian and New Zealand Environment and Conservation Council (ANZECC) and Agriculture and Resource Management Council of Australia and New Zealand (ARMCANZ). www.ea.gov.au/water/nwqms/index.html. Accessed 25 Sep 2013 
APHA, AWWA, WEF (1995) Standard methods for the examination of water and wastewater, 19th edn. American Public Health Association, American Water Works Association and Water Environment Federation, Washington, DC

Austin CM (1985) Introduction of the yabbie, Cherax destructor (Decapoda: Parastacidae) into southwestern Australia. West Aust Nat 16:78-82

AWRC (1987) Review of Australia's water resources and water use. Water resources dataset, vol 1. Australian Government Publishing Service, Canberra

Balla SA, Davis JA (1995) Seasonal variation in the macroinvertebrate fauna of wetlands of differing water regime and nutrient status on the Swan Coastal Plain, Western Australia. Hydrobiologia 299:147-161

Bayly IAE (1967) The general biological classification of aquatic environments with special reference to those of Australia. In: Weatherly AH (ed) Australian inland waters and their fauna: eleven studies. Australian National University Press, Canberra

Beatty S, Morgan D, Gill H (2005) Role of life history strategy in the colonisation of Western Australian aquatic systems by the introduced crayfish Cherax destructor Clark, 1936. Hydrobiologia 549:219-237

Blinn DW, Halse SA, Pinder AM, Shiel RJ, McRae JM (2004) Diatom and micro-invertebrate communities and environmental determinants in the Western Australian wheatbelt: a response to salinisation. Hydrobiologia 528:229-248

Bray JR, Curtis JT (1957) An ordination of the upland forest communities of Southern Wisconsin. Ecol Monogr 27:325-349

Bunn SE, Davies PM (1992) Community structure of the macroinvertebrate fauna and water quality of a saline river system in south Western Australia. Hydrobiologia 248:143-160

Cale DJ, Halse SA, Walker CD (2004) Wetlands monitoring in the Wheatbelt of south-west Western Australia: site descriptions, waterbird, aquatic invertebrate and groundwater data. Conserv Sci West Aust 5:20-135

Carver SS, Spafford H, Storey AW, Weinstein P (2009) Dryland salinity and the ecology of Ross River Virus: the ecological underpinnings of the potential for transmission. Vector Borne Zoonotic Dis 9:611-622

Clarke KR (1993) Non-parametric multivariate analyses of changes in community structure. Aust J Ecol 18:117-143

Clarke KR, Gorley RN (2006) PRIMER v6: user manual/tutorial, Primer E: Plymouth. Plymouth Marine Laboratory, Plymouth

Clarke KR, Green RH (1988) Statistical design and analysis for a "biological effects" study. Mar Ecol Prog Ser 46:213-226

Clarke KR, Warwick RM (1994) Changes in marine communities: an approach to statistical analysis and interpretation. Natural Environment Research Council, Plymouth Marine Laboratory, Plymouth

Clarke KR, Warwick RM, Brown BE (1993) An index showing breakdown in seriation, related to disturbance in a coralreef assemblage. Mar Ecol Prog Ser 102:153-160

Davis J, Christidis F (1997) A guide to wetland invertebrates of Southwestern Australia. Western Australian Museum, Perth
Davis JA, Rolls SW (1987) A baseline biological monitoring programme for the urban wetlands of the Swan Coastal Plain, Western Australia. Bulletin 256. Environmental Protection Authority, Perth

Davis J, Maguire M, Halse S, Hamilton D, Horwitz P, McComb A, Froend R, Lyons M, Sim L (2003) What happens when you add salt: predicting impacts of secondary salinisation on shallow aquatic ecosystems by using an alternativestates model. Aust J Bot 51:715-724

Environment Australia (2001) A directory of important wetlands in Australia, 3rd edn. Environment Australia, Canberra

Froend RH (1987) Effects of salinity and waterlogging on the vegetation of Lake Toolibin, Western Australia. Aust J Ecol 12:281-298

Gentili J (1972) Australian climate patterns. Thomas Nelson, Melbourne

George R, Clarke J, English P (2006) Modern and palaeographic trends in the salinisation of the Western Australian Wheatbelt. In: Proceedings of the Australian Earth Sciences Convention 2006, Melbourne

Gooderham J, Tsyrlin E (2002) The waterbug book: a guide to freshwater macroinvertebrates of temperate Australia. CSIRO Publishing, Collingwood

Griffith MB, Kauffman PR, Herlihy AT, Hill BH (2001) Analysis of macroinvertebrate assemblages in relation to environmental gradients in rocky mountain streams. Ecol Appl 11:489-505

Halse SA, Pearson GB, McRae JM, Shiel RJ (2000) Monitoring aquatic invertebrates and waterbirds at Toolibin and Walbyring Lakes in the Western Australian wheatbelt. J R Soc West Aust 83:17-28

Halse SA, Ruprecht JK, Pinder AM (2003) Salinisation and prospects for biodiversity in rivers and wetlands of southwest Western Australia. Aust J Bot 51:673-688

Ham KD, Pearsons TN (2000) Can reduced salmonid population abundance be detected in time to limit management impacts? Can J Fish Aquat Sci 57:17-24

Hammer UT (1986) Saline lake ecosystems of the world. Junk, Dordrecht

Hammer UT, Sheard JS, Kranabetter J (1990) Distribution and abundance of littoral benthic fauna in Canadian prairie saline lakes. Hydrobiologia 197:173-192

Hart BT, McKelvie JD (1986) Chemical limnology in Australia. In: DeDeckker P, William WD (eds) Limnology in Australia. CSIRO/Junk, Melbourne/Dordrecht, pp 3-31

Hart B, Bailey P, Edwards P, Hortle K, James K, McMahon A, Meredith C, Swadling K (1991) A review of salt sensitivity of Australian freshwater biota. Hydrobiologia 210: 105-144

Hoctor TS, Carr MH, Zwick PD (2000) Identifying a linked reserve system using a regional landscape approach: the Florida ecological network. Conserv Biol 14:984-1000

Hugueny B, Camara S, Samoura B, Magassouba M (1996) Applying an index of biotic integrity based on communities in a West African river. Hydrobiologia 331:71-78

Inland Water Crustacean Specialist Group (1996) Parartemia contracta. In: IUCN 2015. IUCN Red List of Threatened Species. Version 2015.2. www.iucnredlist.org. Accessed 7 July 2015 
Kefford BJ, Nugegoda D (2005) No evidence for a critical salinity threshold for growth and reproduction in the freshwater snail Physa acuta. Environ Pollut 134:377-383

Kefford BJ, Dalton A, Palmer CG, Nugegoda D (2004) The salinity tolerance of eggs and hatchlings of selected aquatic macroinvertebrates in south-east Australia and South Africa. Hydrobiologia 517:179-192

Kefford BJ, Nugegoda D, Metzeling L, Fields EJ (2006) Validating species sensitivity distributions using salinity tolerance of riverine macroinvertebrates in the southern Murray-Darling Basin (Victoria, Australia). Can J Fish Aquat Sci 63:1865-1877

Levy K (2004) Neglected consequences: role of introduced aquatic species in the spread of infectious diseases. EcoHealth 1:296-305

Lymbery AJ, Doupé RG, Pettit NE (2003) Effects of salinisation on riparian plant communities in experimental catchments on the Collie River, Western Australia. Aust $\mathrm{J}$ Bot 51:667-672

Lynas J, Lindhjem P, Storey AW, Knott B (2004) Is the yabby, Cherax destructor (Parastacidae) in Western Australia an ecological threat? Freshw Crayfish 14:37-44

Lynas J, Storey AW, Armstrong K, Prince J, Knott B (2006) Invasion by the exotic crayfish, Cherax destructor Clark (Parastacidae), into habitats of local crayfish near Perth, Western Australia. Freshw Crayfish 15:176-188

Lynas J, Storey AW, Knott B (2007) Aggressive interactions between three species of freshwater crayfish of the genus Cherax (Decapoda: Parastacidae): potential for competitive exclusion. Mar Freshw Behav Physiol 40:105-116

Lyons MN, Halse SA, Gibson N, Cale DJ, Lane JAK, Walker CD, Mickle DA, Froend RH (2007) Monitoring wetlands in a salinizing landscape: case studies from the Wheatbelt region of Western Australia. Hydrobiologia 591:147-164

Marshall NA, Bailey PCE (2004) Impact of secondary salinisation on freshwater ecosystems: effects of contrasting, experimental, short-term releases of saline wastewater on macroinvertebrates in a lowland stream. Mar Freshw Res 55:509-523

McElvray EP, Lamberti GA, Resh VH (1989) Year-to-year variation in the aquatic macroinvertebrate fauna of a northern California stream. J N Am Benthol Soc 8:51-63

McMaster KA, Savage A, Finston T, Johnson MS, Knott B (2007) The recent spread of Artemia parthenogenetica in Western Australia. Hydrobiologia 576:39-48

Minshall GW (2003) Responses of stream benthic macroinvertebrates to fire. For Ecol Manag 178:155-161

Miserendino ML, Brand C, Di-Prinzio CY (2008) Assessing urban impacts on water quality, benthic communities and fish in streams of the Andes Mountains, Patagonia (Argentina). Water Air Soil Pollut 194:91-110

Morrissy NM, Cassells G (1992) Spread of the introduced yabbie, Cherax albidus Clark 1936, in Western Australia. Fisheries Research Report, 92. Fisheries Department, Western Australia, pp 1-27

Naiman RJ, Décamps H (1997) The ecology of interfaces: riparian zones. Annu Rev Ecol Syst 28:621-658

Nielsen DL, Brock MA, Rees GN, Baldwin DS (2003) Effects of increasing salinity on freshwater ecosystems in Australia. Aust J Bot 51:655-665
NLWRA (2001) Australian dryland salinity assessment 2000: extent, impacts, processes, monitoring and management options. National Land and Water Resources Audit, Canberra

Nyström PC, Brönmark C, Granéli W (1999) Influence of an exotic and a native crayfish species on a littoral benthic community. Oikos 85:545-553

Palmer CG, Scherman PA (2000) Application of an artificial stream system to investigate the water quality tolerances of indigenous, South African, riverine macroinvertebrate. WRC Report No. 686/1/00. Water Research Commission, Pretoria

Pannell DJ (2001) Counting the costs: economic aspects of salinity in Wheatbelt valleys of Western Australia. Sustainability and Economics in Agriculture Working Paper 01/06

Pannell DJ, Ewing MA (2006) Managing secondary dryland salinity: options and challenges. Agric Water Manag 80:41-56

Pimentel D, Zuniga R, Morrison D (2005) Update on the environmental and economic costs associated with alien invasive species in the United States. Ecol Econ 52:273-288

Pinder AM, Halse SA, McRae JM, Shiel RJ (2004) Aquatic invertebrate assemblages of wetlands and rivers in the Wheatbelt region of Western Australia. Rec West Aust Mus Suppl 67:7-37

Pinder AM, Halse SA, McRae JM, Shiel RJ (2005) Occurrence of aquatic invertebrates of the Wheatbelt region of Western Australia in relation to salinity. Hydrobiologia 543:1-24

Porst G, Naughton O, Gill L, Johnston P, Kenneth Irvine K (2012) Adaptation, phenology and disturbance of macroinvertebrates in temporary water bodies. Hydrobiologia 696:47-62

Remigio EA, Hebert PDN, Savage A (2001) Phylogenetic relationships and remarkable radiation in Parartemia (Crustacea: Anostraca), the endemic brine shrimp of Australia: evidence from mitochondrial DNA sequences. Biol J Linn Soc 74:59-71

Richardson J, Keighery G, Manson W (2005) A baseline of vegetation health for the Buntine-Marchagee Recovery Catchment. Department of Conservation and Land Management, Geraldton

Rozema J (1975) The influence of salinity, inundation and temperature on the germination of some halophytes and non-halophytes. Oecol Plant 10:341-353

Shiel RJ (1995) A guide to identification of rotifers, cladocerans and copepods from Australian inland Waters. Identification Guide No. 3. Cooperative Research Centre for Freshwater Ecology, Murray-Darling Freshwater Research Centre, Albury, pp 1-144

Smith BJ (1996) Identification keys to the families and genera of bivalve and gastropod molluscs found in Australian inland waters. Cooperative Research Centre for Freshwater Ecology Identification Guide No. 6. In: Presented at the taxonomy workshop held at the Murray-Darling Freshwater Research Centre, Albury, 20-21 February 1996

Smock LA, Stoneburner DL (1980) The response of macroinvertebrates to aquatic macrophyte decomposition. Oikos 35:397-403

Speed R, Strelein M (2004) Groundwater investigation: Buntine-Marchagee Natural Diversity Recovery Catchment. 
Resource Management Technical Report No. 282. Department of Agriculture, Geraldton

Stewart BA, Strehlow KH, Davis J (2009) Impacts of deep open drains on water quality and biodiversity of receiving waterways in the Wheatbelt of Western Australia. Hydrobiologia 619(1):103-118

Storey AW, Halse SA, Shiel RJ (1993) Aquatic invertebrate fauna of the Two Peoples Bay area, southwestern Australia. J R Soc West Aust 76:25-32

Strayer DL, Malcom HM (2007) Submersed vegetation as habitat for invertebrates in the Hudson River Estuary. Estuaries Coasts 30:253-264

Sutherland WJ, Adams WM, Aronson RB et al (2009) One hundred questions of importance to the conservation of global biological diversity. Conserv Biol 23:557-567

Tarr TL, Baber MJ, Babbitt KJ (2005) Macroinvertebrate community structure across a wetland hydroperiod gradient in southern New Hampshire, USA. Wetl Ecol Manag 13:321-334

Timms BV (2004) An identification guide to the fairy shrimps (Crustacea: Anostraca) of Australia. Identification and Ecology Guide No. 47. Cooperative Research Centre for Freshwater Ecology. In: Presented at the taxonomy workshop Lake Hume, 10 and 11 February 2004
Wallace KJ (2001) State salinity action plan 1996: review of the Department of Conservation and Land Management's Programs, January 1997 to June 2000. Report to the Executive Director. Department of Conservation and Land Management, Western Australia

Williams WD (1964) A contribution to the lake typology in Victoria, Australia. Int Ver Theor Angew Limnol Verh 15:158-163

Williams WD (1981) The limnology of saline lakes in Western Victoria: a review of some recent studies. Hydrobiologia 82:233-259

Williams WD (2001) Anthropogenic salinisation of inland waters. Hydrobiologia 466:329-337

Wollheim WM, Lovvorn JR (1995) Salinity effects on macroinvertebrate assemblages and waterbird food webs ion shallow lakes of the Wyoming High Plains. Hydrobiologia 310:207-223

Zukowski S, Walker KF (2009) Freshwater snails in competition: alien Physa acuta (Physidae) and native Glyptophysa gibbosa (Planorbidae) in the River Murray, South Australia. Mar Freshw Res 60:999-1005 